\title{
BELLE ÉPOQUE LITERÁRIA \\ E MODERNISMO: OSWALD DE ANDRADE, INTELECTUAL ENTRE DOIS MUNDOS
}

\section{Rubens de Oliveira Martins}

Resumo. Este trabalho realiza uma reflexão sobre os limites da autonomia da vida intelectual em São Paulo nas primeiras décadas do século XX. Acompanhando a trajetória do escritor Oswald de Andrade desde sua participação nos círculos boêmios do Rio de janeiro até sua atuação como "ponta de lança" do Movimento Modernista em São Paulo, em 1922, estaremos analisando como o processo de institucionalização operado na esfera da cultura foi definindo um padrão para o reconhecimento e a legitimação da vida intelectual.

Palavras-chave: indivíduo e sociedade; vida intelectual; Modernismo; autonomia; institucionalização.

\section{Introdução}

O objetivo deste ensaio é perceber os fatores que definem os limites da atuação do intelectual dentro do contexto social de uma época,

Rubens de Oliveira Martins é mestre em Sociologia pela USP e doutorando em Sociologia pela UnB. Professor das Faculdades Integradas da UPIS e assessor do Dept ${ }^{\circ}$ de Política do Ensino Superior da SESu/MEC. Autor do livro Um Ciclone na Paulicéia-Oswald de Andrade e os limites da vida intelectual em S. Paulo, pela Editora do C. Universitário Ibero-Americano, 2001. Tem artigos nas seguintes publicações: Revista Múltipla n. ${ }^{\text {os: }}$ 5,7 e 8 - Revista das Faculdades Integradas da UPIS; Revista Plural n. os: 5 e 6 - Revista do Programa de Pós-Graduação em Sociologia da Universidade de São Paulo; Revista Sociedade e Estado do Dept ${ }^{\circ}$ de Sociologia da Universidade de Brasília. (2000). 
os grupos aos quais está filiado, os grupos antagônicos, bem como as diferentes formas de influência e de pressão a que está submetido.

Percebendo a variedade de atuações possíveis dentro do plano cultural de uma época, tentaremos divisar a existência de um certo "tipo" de intelectual que, destacando-se do padrão firmado na tradição acadêmica, se torna possível apenas pelo confronto contínuo com seus contemporâneos, como tentativa de afirmação e de superação de um status que tende a se repetir e se cristalizar em instituições.

Para realizar esta tarefa pretendemos analisar a trajetória do escritor modernista Oswald de Andrade até início dos anos 20, sua estréia como jornalista e seu convívio no círculo literário da Belle Époque do Rio de Janeiro.

Entendemos Oswald de Andrade como um paradigma privilegiado de uma posição que chamaremos de "marginal" dentro do sistema cultural inaugurado com o êxito do Modernismo paulista e seus desdobramentos. Portanto, sua "marginalidade" significaria tornar-se um intelectual que "destoa" dos demais, possibilitando uma análise que revela, através do contraste, as possibilidades que se apresentavam então no campo intelectual do período.

A atualidade desta discussão está ligada ao problema recorrente da liberdade e da autonomia do intelectual dentro de um campo de forças delimitado, uma vez que este passa a identificar-se com a cristalização de valores, métodos e classificações pré-definidas, revelando os interesses específicos de algumas áreas do saber acadêmico relacionadas ao exercício e manutenção de status e poder.

A partir desta questão e desta postura, ocorre a cristalização dos parâmetros para o reconhecimento social do intelectual, forjados em comportamentos bem definidos e em um vocabulário preciso e delimitado ao universo de seus pares, formando como que "feudos" de um saber institucional, onde há limites para a emergência do "novo" e as tentativas de oposição enfrentam estratégias de deslegitimação que limitam a autonomia do trabalho intelectual, uma vez que se cria uma prisão conceitual a partir de valores definidos e cristalizados.

Assim, a liberdade do intelectual fica confinada à aceitação daquelas orientações e valores pré-determinados, e a sua autonomia dissolvese na necessidade de reconhecimento e legitimação que passa pela instituição burocrática e suas exigências. 
As posições possíveis que o campo intelectual delimita em um certo momento de sua vigência refletem sempre a dimensão dos limites e dos controles associados, onde, através dos processos de diferenciação e explicitação dos contrastes, fazem valer sua visão de mundo correspondente.

No caso específico do fenômeno que nos interessa, o do Modernismo paulista, percebemos também a presença de uma cristalização operada na explicitação de uma diferença fundamental entre duas posturas distintas entre seus principais intelectuais: de um lado, Mário de Andrade, visto como intelectual símbolo, rigoroso e sério, ligado ao Departamento Municipal de Cultura e responsável pela fundamentação dos novos princípios estéticos nacionais; de outro lado, Oswald de Andrade, "clown" da burguesia, íntimo da sátira e da vanguarda estética, porém tendo suas potencialidades de participação no campo intelectual dominante limitadas por sua personalidade "não séria", que o levou a ser visto como o "calcanhar de Aquiles" do Modernismo nacional.

Pretendemos superar esta dicotomia construída, falsa e simplificadora, que tenta explicar as coisas através de posições "contra" ou "a favor" de Oswald ou de Mário, e que é explicitada na história da literatura e nos círculos informais. Tal perspectiva acabou por se tornar dominante e encontrou ressonância em abordagens de cunho sociológico aliadas ao refinamento da introdução de elementos teóricos de outras correntes do pensamento social.

Aqui podemos perceber a existência de uma configuração onde emergem dois mundos diferentes: o da liberdade construída nos limites da diferenciação possível e o da liberdade delimitada pela normatização oficial, que se comunicam e se complementam através das tênues fronteiras identificadas nas posturas daqueles indivíduos em que o balanceamento das escolhas para "entrar na sociedade" encontramse referidas às decisões de um alinhamento mais ou menos acentuado ou com a identificação imediata ou com a marginalidade possível.

Uma genealogia do processo de conformação do campo intelectual em que Oswald de Andrade iria atuar precisa analisar o impacto da herança da boêmia e a situação de transição dos intelectuais nos fins do século XIX. 
Assim, para compreender o contexto em que se situam os intelectuais nas primeiras décadas do século no Brasil, primeiro será necessário empreender um esforço de reconstrução histórica da vida intelectual no período imediatamente anterior à ruptura modernista de 1922, ou seja, acompanhar o que caracterizava a vida na "República das Letras" centralizada no Rio de Janeiro e o processo de difusão e declínios de seus padrões, para poder compreender as possibilidades de carreira intelectual existentes e delinear suas exigências, a fim de verificar o tipo de sociabilidade em mutação que esta vida intelectual já espelhava.

Para isto a análise da vida intelectual na primeira década do século na capital da república vai ilustrar como, a partir da criação da Academia Brasileira de Letras, o tipo de intelectual caracterizado pelo escritor-boêmio passa a ser substituído pelo intelectual cuja seriedade estava regrada por aquela instituição.

Neste sentido, a discussão sobre a atividade intelectual que aqui empreendemos não objetiva definir uma construção formalizada e absoluta que oponha a boêmia à integração do intelectual, mas demonstrar a nova conformação dos limites daquele tipo de sociabilidade.

Se é verdade que jamais ocorreu uma ruptura completa que apartasse a atividade intelectual da sociabilidade boêmia, fica patente o fato de que, com a fundação da Academia de Letras, torna-se legítima a boêmia dourada dos salões, no lugar daquela boêmia típica dos tempos de Emílio de Menezes.

Além disso, a idéia de que a institucionalização da vida intelectual define novas formas de sociabilidade entre os indivíduos que dela participam não significa simplesmente a abolição de uma sociabilidade boêmia, que se torna então o espaço sempre presente onde é possível experimentar uma certa liberdade em relação aos laços institucionais.

Portanto, naquele momento de mudança de estilos de comportamento e de legitimação da vida intelectual, já era possível vislumbrar a figura de Oswald de Andrade como que se tornando um intelectual "entre dois mundos", cuja atuação idiossincrática somente pode ser compreendida por uma dupla determinação: pelos vestígios de uma herança da vida intelectual da boêmia carioca e pela especificidade de sua posição de classe, que lhe dava as condições materiais para transformá-lo em um intelectual independente das modalidades 
tradicionais de inserção, definindo uma nova forma de atuação na vida intelectual.

\section{Entre a boêmia e a seriedade}

Para analisar a vida intelectual no período das primeiras décadas do século XX no Brasil, é preciso compreender os caminhos através dos quais foi sendo construída a imagem do intelectual, percebida de forma interna aos grupos detentores do monopólio legítimo de uma arte reconhecida, e também de forma externa a estes grupos, ou seja, o modo como eles eram identificados pelo grande público.

A questão que se coloca é o contraponto entre a vida cultural herdada dos últimos anos do Império, com sua estrutura e valores definidos, e as novas situações que surgem para o pensamento e para a sociedade, no bojo das transformações vividas nestas primeiras décadas do século.

Com isso vamos perceber que há, claramente, uma primeira clivagem entre, por um lado, as atitudes de uma intelectualidade boêmia, remanescente de certos vestígios do Romantismo em suas atitudes e vivências e, por outro lado, uma modificação destes valores pela instituição de um novo modo de comportamento social mais de acordo com a mentalidade "civilizada" da época.

Acompanhar estas transformações no campo intelectual é tarefa que exige considerar a análise das instituições que são criadas neste percurso, bem como a análise das formas de representação e de reconhecimento dos intelectuais dentro do imaginário da sociedade contemporânea a eles.

Enquanto estivermos analisando tal processo, pretendemos privilegiar a atuação de Oswald de Andrade, que tem sua estréia na vida literária do período submetida ao modelo e às regras existentes e, ao mesmo tempo, vai também trazer consigo a marca da tensão e da ambigüidade decorrente deste tipo de inserção, uma vez que estaria situado a meio caminho entre aquela via tradicional de atuação intelectual e uma via que incorporaria a inquietude e a ruptura com o passado dentro do contexto da conjugação dos fatores políticos, sociais, culturais e pessoais com os quais se defronta. 
Desta forma será possível perceber como a contradição desta estréia definirá um processo que se transformaria na característica inerente a este autor: uma condição sui generis de indefinição ou de deslocamento, uma vez que, defrontando-se com a tradição estabelecida, sua atuação será definida pela incorporação de vestígios de uma postura herdada da boêmia, em que a liberdade e a autonomia eram os sinais que distinguiam o intelectual na sociedade.

A fundação da Academia Brasileira de Letras em 1896, presidida por Machado de Assis, foi o marco decisivo para que se iniciasse uma mudança nos padrões de comportamento e reconhecimento dos intelectuais.

Ocorre que, até este momento, o intelectual, sinônimo de homem de letras, ainda carregava traços da sua origem em grupos boêmios da Rua do Ouvidor, na capital da República.

O intelectual, cujo estereótipo era o do artista desajustado, cede lugar ao intelectual comportado e portador de uma compostura condizente com aquela dignidade oficial da qual Machado de Assis era o exemplo máximo, postura que levará Oswald de Andrade, em suas memórias de 1954, a identificar esta circunspecção cultivada por Machado como um certo recalque do autor de Dom Casmurro, na tentativa de livrar-se da marca étnica:

Como bom preto, o grande Machado o que queria era se lavar das mazelas atribuídas à sua ascendência escrava. Fazia questão de impor rígidos costumes à instituição branca que dominava. (Andrade, 1976, p.77)

A modernização da cidade do Rio de Janeiro em 1904, pelo prefeito Pereira Passos, viria também demarcar o fim de uma sociabilidade boêmia, fundada nos laços do companheirismo das conversas fáceis e dos encontros inevitáveis nos limites da Rua do Ouvidor, que definia um mundo de dimensões reduzidas e estreitas, onde a presença quotidiana e a despreocupação marcavam o tom dos relacionamentos.

As mudanças na geografia da cidade irão colocar um fim àquele espaço delimitado, uma vez que as novas e largas avenidas já não possibilitavam aquela proximidade e atuavam como fator de dispersão 
dos antigos costumes, implicando na crescente perda de prestígio do intelectual boêmio, cada vez mais deslocado para uma posição hierárquica inferior, como que caracterizando um passado "não civilizado" que deveria ser apagado pelo progresso.

A presença da tecnologia, e sua apologia na figura do automóvel, já se mostrava um processo capaz de "contaminar" a todos, não sendo aleatório o fato de que um dos primeiros automóveis foi trazido por José do Patrocínio, escritor boêmio e homem público envolvido nas lutas sociais em prol da abolição.

A empolgação com a "era da velocidade" e do progresso não deixava incólume os escritores e intelectuais do período, sendo que a esse respeito, conta Luiz Edmundo que, tentando ensinar Bilac a guiálo, acabaram por perder o controle e colidir, fazendo com que Bilac se julgasse "o precursor dos desastres de automóveis no Brasil" (Broca, 1956, p.15).

A noção de "civilidade" que se instalava na capital da república, como índice de inserção na modernidade inspirada em Paris, trazia junto consigo os valores da utilidade prática e da eficiência, deslocando para a margem os traços que pudessem lembrar à cidade sua antiga situação de precariedade.

Tal processo corresponderia ao aburguesamento dos escritores que desejassem manter sua "vigência" (Neto, 1973), sendo deles exigida a atitude de negação da boêmia para que pudessem inserirse naquele meio político e cultural que se estruturava a partir dos primeiros anos da república, já mediados por instituições como a Academia de Letras.

$\mathrm{Na}$ esteira das lutas e oposições entre os diferentes grupos no âmbito cultural, era certo que esta transformação sofresse a resistência de vários boêmios históricos como Paula Ney, que se opôs ao grupo de Machado de Assis através da fundação da Academia Livre de Letras, como forma de protesto e tentativa de aglutinação daqueles escritores que haviam sido preteridos pela instituição oficial, expressando o desajuste social do intelectual boêmio.

A existência de tal oposição não foi porém suficiente para contrapor-se à "irresistível" força de atração da Academia oficial, sendo que houve casos famosos de antigos boêmios, entre eles Emílio de Menezes e Lima Barreto, que acabaram por "bater-lhe às portas", 
ainda que durante um certo período não houvessem poupado críticas àquela instituição.

O caso de Emílio de Menezes é interessante como paradigma dos costumes literários vigentes: durante a vida de Machado de Assis não havia conseguido jamais ser eleito para a Academia, uma vez que o mestre não toleraria seu comportamento jocoso e boêmio, considerando-o como o exemplo mais categórico da incompatibilidade entre o culto elevado das preocupações culturais e o desregramento inconseqüente da boêmia despreocupada.

Emílio de Menezes era a imagem típica do boêmio que havia marcado o período anterior ao processo de institucionalização da vida literária, fazia quadras bem humoradas e muitas vezes ferinas.

De acordo com o depoimento de Oswald de Andrade, Emílio costumava ficar à porta das confeitarias conversando, destilando sua sátira que tanto amedrontava a todos, enfim, vivendo dos expedientes típicos da vida boêmia.

Oswald de Andrade relembraria, em 1945, um episódio da época em que Emílio de Menezes tinha como companheiros de boêmia Bilac, Paula Ney e Coelho Neto, ilustrando bem aquela defasagem de postura que seria tão criticada por Machado de Assis:

Para reforçar o rancho do grupo incumbira-se de arranjar na confeitaria de um alemão restos de presunto e salame dizendo que era para um cachorro. Cada vez pedia mais. - O cachorro está crescendo. Um boião de picles aguçava-lhe a gula. Uma tarde não se conteve mais: 'Ponha uns picles aí!'. 'Sua cachorra come picles?', gritou o alemão botando-o para fora. (Andrade, 1992, p.77)

Após a morte de Machado de Assis, Emílio de Menezes finalmente foi eleito, em 1914, para a vaga de Salvador de Mendonça, e segundo o depoimento de Medeiros de Albuquerque, Emílio acabou sendo eleito pelo "medo" que incutia em seus pares:

Muitos acadêmicos receavam as sátiras do poeta, que faziam todo mundo rir e eram 'modelos de perversidade. (Broca, 1956, p.19)

Neste procedimento é preciso reter que o momento de cristalização da Academia parecia estar ainda em construção pois, se por um lado Emílio de Menezes tinha laços de antiga amizade com os já consa- 
grados acadêmicos Bilac e Coelho Neto - fato que sem dúvida pesou para sua eleição -, por outro lado tinha contra si todo o peso de ser considerado o símbolo vivo do antiacadêmico.

Desta forma, elegendo-o, a Academia parece demonstrar certa indecisão ainda sobre a forma como desejaria ser reconhecida pela sociedade, uma vez que cede ao medo nesta eleição; porém, podemos também antever, nesta decisão, a presença de uma estratégia de cooptação daqueles elementos que poderiam ser perigosos se deixados "livres" de seu controle direto.

O que se destaca no episódio da eleição de Emílio de Menezes é o fato de que em seu discurso de posse se defendia enfaticamente da pecha de boêmio, assumindo uma atitude de negação daquelas mesmas atitudes que o fizeram reconhecido e temido, fato que gerou o seguinte comentário vindo de Coelho Neto: "E dizer que isto é o discurso de um homem de espírito".

O caso de Lima Barreto apresentava-se mais complexo, pois além de boêmio, lutava contra o racismo e o fato de ser alcoólatra. A iniciação na boêmia literária se dá no contato com escritores como Luiz Edmundo e na organização da revista "Diabo" junto com Bastos Tigre.

A atitude coerente de intelectual que não admite compactuar com o elitismo literário do período, nem com a frivolidade do mundanismo da época, optando, pelo contrário, a lidar com temas sociais e cotidianos segundo uma incômoda visão crítica, serão os fatores que o incompatibilizarão permanentemente com a instituição acadêmica.

Enfim, numa atitude que atesta a clareza e o realismo de sua visão, Lima Barreto acaba por desistir da Academia, comentando em carta com o amigo Monteiro Lobato:

Sei bem que não dou para a Academia e a reputação de minha vida urbana não se coaduna com a sua respeitabilidade. (apud Broca, s/d., p.18)

Chegou-se pois a uma época onde diferentes estilos de vida travam uma luta pela hegemonia e legitimação de idéias, demonstrando o nascimento de uma estratégia de domesticação e de legitimação oficial em processo de formação, que será responsável pela marginalização daqueles que não se enquadrarem nos seus cânones. 
Comentando ainda a marginalização de Lima Barreto pela elite cultural, havia ainda o paradoxo de que o poder de exclusão das instituições, para além de um sinal de força, atestaria um permanente estado de insegurança destas mesmas elites, uma vez que para se manterem no poder precisavam excluir quaisquer índices de questionamento ou de incertezas, ou, nas palavras de Sevcenko:

O horror ao impulso criativo individual figurava um estado de congelamento da sociedade em que somente a estagnação e a repetição eram premiadas, justamente por consagrarem o mesmo, o intocável. Ai está a raiz da 'república dos medíocres' e da paralisação da imaginação (...) O saber era apanágio das instituições tuteladas. O próprio Machado de Assis, zeloso na preservação de sua Academia de Letras recém fundada, definia-lhe severo os limites... (Sevcenko, 1989, p.216)

O exercício de uma censura e de um controle sobre os intelectuais absorvidos pela legitimação oficial pode ser encontrado também nas restrições "sutis" da própria sociedade conservadora e suas instituições, como foi o caso do boicote sistemático ao nome de Lima Barreto pelo Correio da Manhã (Neto, 1973, p.117), considerado como persona non grata.

A nova forma de vida literária era expressada exemplarmente nas palavras de João do Rio, nas quais já surge a consciência de uma nova temporalidade definida pela "modernidade", quando não é mais possível "perder tempo" naquelas "conversas teóricas estéreis" que tinham lugar nos cafés:

Os tempos mudaram, meu caro. Há vinte anos um sujeito para fingir de pensador começava por ter a barba por fazer e o fato cheio de nódoas. Hoje, um tipo nestas condições seria posto fora até mesmo das confeitarias, que são e sempre foram a colméia dos ociosos. Depois, há a concorrência, a tremenda concorrência do trabalho que proíbe romantismos, o sentimentalismo, as noites passadas em claro e essa coisa abjeta que os imbecis divinizam chamada boêmia, isto é, a falta de dinheiro, o saque eventual das algibeiras alheias e a gargalhada de troça aos outros com a camisa por lavar e o estômago vazio.... (Rio, 1994, p.294)

Assim, se o intelectual boêmio era o personagem de uma época onde a institucionalização do campo intelectual ainda não se fazia sentir 
com toda sua força, emergia agora um novo sentido de institucionalização do campo intelectual, que passa a ser caracterizado como o espaço do trabalho lucrativo e legitimado, conferidor de status e poder social e político.

As tentativas de inserir-se nos domínios desta nova realidade, que teve como contrapartida a esterilidade da vida literária no período, foram marcadas pela substituição da vocação literária pela profissão literária, isto é, a precariedade da atividade intelectual mostrava-se claramente pelo fato de que, para viver de literatura, era preciso que se aliasse ao jornalismo e se submetesse ao processo de mercantilização das letras, onde começavam a proliferar os escritos "de encomenda", expediente necessário para a subsistência dos intelectuais.

Da mesma forma, a atividade literária de Aluísio Azevedo tornase praticamente nula após seu ingresso na carreira diplomática, quando se torna vice-cônsul em Vigo, em 1896. A partir de então, não mais dependendo da literatura como forma de profissão, passa a adiar continuamente os projetos literários que jamais realizaria e, chega mesmo a desabafar a Coelho Neto:

Escrevo por força da fatalidade. Dão-me as letras para viver, mas eu é que sei como vivo! Digo-te apenas que no dia - que aliás não espero - em que conseguisse alguma coisa que me garantisse o teto e a mesa, deixava de mão a pena, papel e tinta, todas estas burundangas que só têm servido para incompatibilizar-me com o clero, nobreza e povo. De letras estou até aqui. Meu ideal é um emprego público... (apud Broca s/d., p.29)

A partir desse momento, a imagem do intelectual e do homem de letras passa por um processo de transformação, descaracterizando aquele modelo de boêmia literária, uma vez que nesta nova realidade a dimensão cultural de sua produção contava menos que sua capacidade de aproveitar-se daquele "ofício" de forma a instrumentalizá-lo.

Desta forma, no processo simultâneo de banalização da literatura e de multiplicação de jornais e revistas de influência, aliado ao fato da iminente valorização do discurso intelectual dentro da lógica de legitimação das ações governamentais, "ser intelectual" passa a ser o "requisito indispensável para conseguir as cavações e os empregos públicos, e 
principalmente a chave mestra das portas cobiçadas da política e da diplomacia" (Sevcenko, 1989, p.99).

Enfim, a substituição daqueles ideais cultivados pelos homens de letras na transição do império para a república, revelou um processo em que aqueles "mosqueteiros intelectuais", conforme os descreve Sevcenko, transformaram-se em "paladinos malogrados", desiludidos com as promessas não cumpridas pelos governos republicanos: ou tornaram-se marginais - mosqueteiros sem missão - ou adaptaramse ao que a realidade do sistema exigia.

A época dos cafés e das livrarias significava o contrário da época da instituição da Academia: a literatura existia e era vivida pelos escritores, não era uma realidade separada e objetivada, exaltando os ânimos uma vez que compreendia a totalidade da existência.

Assim torna-se compreensível o clima de guerrilha constante entre os grupos que se reuniam nos diferentes cafés e que defendiam a superioridade de suas escolas contra os "inimigos", utilizando apenas as armas da palavra escrita, sempre imbuída de uma linguagem bélica que canalizava a agressividade dos combates e servia também aos propósitos de definir uma classificação entre estes grupos, já revelando as disputas pela hegemonia do debate intelectual.

\section{(...) é Bilac satirizando um medíocre qualquer e Emílio de Menezes 'enterrando' a celebridade do dia com seus temíveis epitáfios(...) Custa-nos acreditar em semelhante atitude em nossos dias, quando ninguém mais se intimida com tais armas. (...) Nos grupinhos de cafés e confeitarias, essas perfídias encontravam grande resso- nância, acumulando sobre a 'vítima' grande carga de ridículo. (Broca, 1956, p.46)}

A boêmia literária significava então uma abertura para o exercício da liberdade intelectual, fora do controle de quaisquer instituições, como que criando um ponto de observação e de protesto em relação à situação cultural vigente.

Nas palavras de Antônio Cândido, a boêmia pode ser vista como:

a reação ante a ordem excessiva por parte do boêmio e do estudante, que muitas vezes eram o escritor antes da idade burocrática. Este elemento renovador e dinamizador acabou por ser parcialmente 
racionalizado pelas ideologias dominantes, esboçando-se nos costumes certa simpatia complacente pelo jovem irregular, que antes de ser homem grave quebrava um pouco a monotonia de nosso Império encartolado, mas nem por isso perdia o benefício de seu apoio futuro. (Cândido, 1985, p.83)

O jogo de forças entre estas duas concepções denuncia o momento de transformação por que passava a sociedade, onde a multiplicidade de novos símbolos determinava a diferenciação da realidade vivida por cada sujeito, que aderia a um sistema de práticas conectadas com as expressões que a realidade estava instituindo no processo de "fazer-se".

Neste processo adquire importância o trabalho do jornalismo literário que criava as novas condições para a existência de uma vida intelectual, fato que não passou despercebido pelo inquérito de João do Rio, no qual grande parte dos entrevistados via o jornalismo como fator favorável à atividade literária.

Neste sentido Olavo Bilac diria que o jornalismo era um "grande bem" para todo escritor brasileiro, uma vez que era o único meio para que ele pudesse ser lido (Rio, 1994, p.18).

Da mesma forma Silvio Romero encara o jornal como o locus da estréia literária e do aprendizado da palavra escrita, sendo também o veículo através do qual os homens de letras influenciam os destinos do país (Rio, 1994, p.50).

Ocorre, porém, que o jornalismo acaba por definir um novo espaço e uma nova forma para a atividade literária: já não havia mais os grandes espaços reservados para os folhetins literários, que foram paulatinamente substituídos pela coluna de crítica ou de resenha, uma vez que o próprio gosto do público começava a tender para as reportagens sobre o cotidiano ou sobre fatos sensacionalistas.

Daí o interesse para as entrevistas e pela vida dos autores mais do que por sua obra, como confessa João do Rio ao realizar o seu inquérito sobre o Momento Literário em 1900, declarando que o momento não era de devaneios mas de curiosidade e informação, transformando a literatura em reportagem, como deseja o público.

O surgimento da categoria do grande público leitor foi um fator fundamental de influência sobre o novo estilo de vida literária, uma vez que as discussões não eram mais privativas dos embates entre os membros das escolas existentes, como no tempo da boêmia, mas 
tornaram-se de interesse público para os leitores dos jornais, ávidos sobre as últimas discussões e modas literárias, que caracterizaram o mundanismo da época.

No período de 1900 tem-se, nas palavras de Brito Broca, uma preponderância da vida literária sobre a literatura, onde importava mais a vida dos escritores, seus pequenos acidentes cotidianos, que a leitura da própria obra.

Sintetizada na fórmula de Afrânio Peixoto segundo a qual a literatura era o "sorriso da sociedade", surge a estratégia que definia a "sobrevivência" e a popularidade do escritor através da sua capacidade de "ser comentado" pelo grande público.

À medida que o Rio de Janeiro "civilizava-se", o mundanismo vai penetrar e influenciar a literatura e a vida literária no período. A antiga boêmia dos cafés cede lugar à uma "boêmia dourada" dos salões, caracterizada exemplarmente pelo "dandismo" de um João do Rio, que através de atitudes esnobes e afetadas pretendia escandalizar - e conquistar - aquela burguesia apartada das elites literárias dos salões.

Humberto de Campos comenta em suas memórias a que ponto chegava este objetivo de tornar-se conhecido:

Paulo (João do Rio) conquistava nomeada dia a dia, e, para conquistá-la, sacrificava seus brios de homem, fazendo constar que praticava as maiores perversões sexuais. O que ele queria era ser discutido, comentado, citado. Que o insultassem, que o injuriassem, mas que o não esquecessem. (Campos, 1954, p.240)

Da mesma forma que João do Rio, outros escritores perceberam a necessidade de adotarem atitudes que os diferenciassem junto ao grande público tornando-os conhecidos; era o caso do que Machado Neto chama de "receitas de vigências" (Neto, 1973, p.185), tais como: estardalhaços publicitários no momento do lançamento de algum livro através da prática do auto-elogio, deixar de mencionar nas crônicas os nomes de outros escritores para não lhes fazer propaganda, adotar atitudes e opiniões esperadas pelo público, mesmo que não concordassem com elas - como o caso de Bilac, que, embora tornado famoso por seus poemas parnasianos em que louvava a natureza, havia confessado sigilosamente a Medeiros de Albuquerque "detestar a natureza" e preferir a vida urbana. 


\section{O Mundanismo Literário em Decadência}

Os vários grupos que se batiam no mundo das letras disputavam também espaços e prestígio no imaginário da época, quando então poderiam ser reconhecidos pelos símbolos que exteriorizavam e [que acabavam por construir uma estética do gestual], complementar àquela estética professada por suas obras.

Atitude condizente com o mundanismo da época era o deslumbramento com Paris, característico da vida literária brasileira desde fins do Império, fato não restrito apenas ao Brasil mas sentido também por toda a Europa e o mundo ocidental, quando então “(...) Auferir da existência tudo quanto ela nos podia dar de belo de bom, era uma receita que então só se aviava no 'boulevard”" (Broca, 1956, p.91).

A atitude comum do homem de letras que visitava Paris era de afetação e deslumbramento com tal civilização:

O chique era mesmo ignorar o Brasil delirar por Paris (...) As Viagens se multiplicavam, o câmbio favorável e as companhias de navegação proporcionando facilidades aos escritores e jornalistas, os jornais, por sua vez, muito interessados em terem correspondentes na Europa. (Broca, 1956, p.93)

Bem diversa virá a ser a atitude dos modernistas paulistas em 1922, também viajantes e visitantes da Cidade Luz, mas que através dela reencontrarão o Brasil, como afirma Paulo Prado no prefácio à Poesia Pau-Brasil de Oswald de Andrade em 1924: "Oswald de Andrade, numa viagem a Paris, do alto de um atelier da Place Clichy - umbigo do mundo - descobriu, deslumbrado, a sua própria terra" (Andrade, 1972, p.5), marcando assim a ultrapassagem do registro de uma literatura "epidérmica" de viagem.

O mundanismo praticado por esta "boêmia dourada" limitava-se a imitar as últimas modas de Paris, nos trajes e na literatura - onde reinava Anatole France.

Tendo decretado o fim do intelectual errante da Rua do Ouvidor, esta nova elite literária reunia-se nos vários salões que surgiram no período, dos quais podemos destacar, no Rio, o salão de Coelho Neto e, em São Paulo, a Vila Kyrial, do senador Freitas Vale, única possibi- 
lidade viável de atuação dos homens de letras neste novo ambiente das convenções sociais que o mundanismo da época definia.

O clima de decadência literária adquire proporções que chegam a atingir a própria Academia Brasileira de Letras, onde Humberto de Campos, ele mesmo um acadêmico, diz-se assustado com o aumento do número de mediocridades dentro daquela casa, não poupando palavras duras em suas memórias sobre as "asneiras" que são ditas por vários acadêmicos, seja em discursos mal elaborados, em citações equivocadas, na ausência de interesse pelos assuntos importantes a serem discutidos, ou mesmo sobre o desinteresse dos editores pelas obras da maioria dos acadêmicos (Campos, 1954, p.258).

Nas entrevistas feitas por João do Rio com os escritores mais importantes em 1900, encontramos também a crítica à Academia de Letras na voz de Frota Pessoa que a compara a uma "sociedade funerária" onde imperaria o marasmo intelectual e a busca de status literário, sendo um local onde "Nunca, jamais, nenhum imortal, ali penetrado, fez, no seu caráter de imortal, outra coisa senão partir para a bem-aventurança" (Rio, 1994, p.175).

O que aparece aqui é a substituição daquele interesse literário que absorvia a vida do intelectual, pelo objetivo de alcançar uma glorificação capaz de influenciar a carreira do intelectual, dentro da lógica da legitimação do mundanismo.

Acompanhando este clima de decadência, os escândalos envolvendo a Academia e seu processo de eleição se sucediam, como no caso da eleição de Mário de Alencar ao invés do escritor veterano Domingos Olímpio em 1905, uma vez que o primeiro era um protegido de Machado de Assis.

Outro caso foi o da eleição de Lauro Muller em 1912, como narra Brito Broca:

Desta vez tratava-se de alguém que não era escritor nem possuía livros publicados, como exigiam os estatutos. Para atender este último requisito, teve o candidato de mandar editar em volume um discurso. Medeiros e Albuquerque, que fiscalizou a impressão dos trabalho em Paris, diz haver escolhido o papel mais grosso e os tipos maiores, não conseguindo assim mesmo fazer com que o 'livro' ultrapassasse as proporções de um simples folheto. Lima Barreto, comentando sarcasticamente o fato, dizia que o discurso fora impresso em papelão e letras garrafais. (Broca, 1956, p.70) 
A Academia começava a distanciar-se daquele ideal de constituirse num repositório de grandes intelectuais para transformar-se em instrumento de prestígio político, submetida a barganhas extra-literárias.

Era natural, então, que em seu interior se formassem "panelas" de interesses que logo levariam a um processo decadente marcado pela troca de insultos entre estes grupos.

Percebemos na vida literária brasileira das primeiras décadas do século também a existência de uma tensão entre uma república das letras oficial e uma boêmia persistente; porém aqui, sua força já se encontrava comprometida pelos esforços de cooptação ou de exclusão completa, capaz de esterilizar quaisquer tentativas de subversão.

Aqui, a boêmia vai adquirir um caráter menos de contestação à uma situação econômica que de contestação estética e de liberdade criativa, pois nela encontraríamos indivíduos cuja preocupação financeira era menor que a preocupação com um estilo de vida contestador.

Mesmo assim, é interessante perceber como aquelas práticas características da antiga boêmia literária - a dos ataques pessoais verbais, dos boatos e de alguns tipos de libelles tupiniquins - voltam a se manifestar dentro de uma instituição como a Academia Brasileira de Letras, que, por ironia, havia sido a responsável pela decadência daquele mesmo estilo de vida literária.

Como ilustração, são exemplares os comentários de Coelho Neto em 1919, citados por Humberto de Campos, a respeito de Paulo Barreto, o João do Rio:

Humberto, eu conheço o Paulo. A cultura do Paulo é uma cultura que eu chamo de 'capa amarela', do 'vient de praitre', cultura de momento, que ele bebe de passagem nas edições Charpentier. Tu já conversaste com o Paulo e sabes que ele é incapaz de demorar-se sobre um assunto: desvia, foge, escapole-se, para não deixar de todo evidente sua ignorância. (Campos, 1954, p.59)

Além destas opiniões que corriam de maneira informal, encontramos episódios mais violentos e que vieram a público na forma de troca de artigos em jornais, como no caso da polêmica entre Silvio Romero e José Veríssimo ocorrida em 1909, onde os ataques chegaram a ser feitos em termos pessoais. 
Sobre o primeiro sabe-se que possuía opiniões extremadas e "espírito de pirraça", enquanto o segundo era admirado por sua objetividade de critérios e equilíbrio de julgamentos. Brito Broca nos fala que:

um dos instrumentos de ataque utilizado a todo instante pelo agressor, é o achincalhe do antagonista por meio de apelido, aliás freqüentemente utilizado por Silvio Romero nas polêmicas... (Broca, 1956, p.188)

A defesa de José Veríssimo foi feita em um artigo de Bandeira de Melo, mas sua principal resposta foi, anos mais tarde, na sua "História da Literatura Brasileira", onde concedeu apenas quatro linhas de texto à obra de Silvio Romero, mostrando um deslize em sua famosa imparcialidade (Broca, 1956, p.191).

Este procedimento de omissão de nomes dos desafetos viria a fazer escola e a tornar-se bastante popular, como demonstra a ausência do nome de Lima Barreto na antologia da literatura brasileira organizada por Manuel Bandeira, bem como a ausência de Oswald de Andrade em uma antologia de poesia brasileira também organizada por Bandeira, o que configura uma mediação de poder baseada ora em idiossincrasias valorativas, mas com mais freqüência em interesses "literários" bastante explícitos.

No caso das polêmicas, os procedimentos mais utilizados eram os ataques aos inimigos através da ridicularização de seus representantes mais eminentes, sendo a contrapartida deste processo o elogio mútuo aos confrades, expedientes que serviam para o reforço da coesão interna destes grupos.

É Oswald de Andrade, que recuperando a polêmica como gênero literário, utilizaria com o brilho de sua personalidade as armas da palavra para este embate, sabedor de que deveria estar atento ao duplo caráter que a polêmica implica: a derrota dos argumentos do adversário e a conquista do interesse do público leitor que, ao cabo, deveria optar pelas idéias defendidas pelo vencedor da contenda.

Percebe-se que Oswald de Andrade e suas sátiras inscrevem-se numa tradição que inclui desde boêmios como Emílio de Menezes até escritores mais "sérios" como Silvio Romero, o que nos sugere um processo de mudança nas formas da vida intelectual, onde o lugar da 
sátira começava a ser proscrito da vida literária, tornando-se, no máximo, tolerada nos momentos vanguardistas de mudança e destruição - sendo aqui privilegiada sua função iconoclasta em detrimento de sua dimensão crítica criadora.

No depoimento de Luiz Edmundo ao inquérito de João do Rio em 1900 já temos a constatação de um início desta "domesticação dos costumes" patrocinado pelo espírito de solenidade da Academia Brasileira de Letras, o que é comparado pelo entrevistado a um processo de decadência literária, onde a fervilhação das disputas literárias que eram vividas plenamente não mais existem:

Já não se diz mais - Fulano é uma besta. Velhos e novos são saldunes que passeiam pela trilha literária, bras dessus bras dessous, risonhos, calmos, indiferentes... (Rio, 1994, p.95)

Esta "domesticação" tem o sentido de uma perda referida ao processo de mediocratização da vida intelectual, decidida não mais pela polêmica criativa, mas pela política de acomodações e elogios mútuos, objetivando a manutenção do status alcançado, que transformava o interesse literário em um negócio oficial.

O novo período da vida literária no começo do século seria então caracterizado, segundo João do Rio, pelo fato de que havia passado o "tempo das ganas, das raivas, das descomposturas. Agora não se ataca mais. Não há tempo. A delicadeza é um resultado da falta de tempo" (Rio, 1994, p.296).

Percebe-se então o novo ritmo adquirido pela vida cultural no período, quando os intelectuais começam a acumular diferentes tipos de atuação: é Bilac fazendo peças de propaganda ("reclames"); é João do Rio dividido entre a crônica mundana nos jornais e seus romances; é a especialização cada vez maior da categoria do crítico literário nos jornais, como José Veríssimo e a necessidade de "coragem" e "objetividade" para poder elogiar ou atacar algum livro (que poderia ser de um amigo seu).

Este processo reflete a mudança operada na condição social dos intelectuais, cada vez mais dependentes do trabalho nas redações dos jornais para garantirem sua sobrevivência, uma vez que pesava contra eles o fator do alto índice de analfabetismo que inviabilizava a renda pela venda de livros, aliada ao fato de que a maioria dos escritores era refém das políticas das casas editoriais. 
Neste momento, o jornalismo já aparece como condição de sobrevivência do escritor, que, desta forma, inseria-se nas lutas partidárias que incluíam as facções oligárquicas detentoras do controle destes jornais (Miceli, 1977).

Daí a importância de o escritor adquirir prestígio social através das várias estratégias citadas, que acabaria por definir os "vitoriosos" e os "derrotados": os primeiros sendo aqueles dignatários da vinculação à república das letras oficial, inseridos em sua lógica onde a produção contínua para um público leitor médio, aliada ao jornalismo mundano e à certeza de apanágios e sinecuras no governo; os últimos, compondo o mundo dos subliteratos marginalizados, alimentando uma hostilidade crescente com a artificialidade e a mediocridade definida por aquela vida literária "sorriso da sociedade".

A existência de grupos de afinidades e de inimizades latentes era uma constante do período e foi um fator sempre ligado às disputas de poder literário, que acabariam por tornarem-se contendas pelo prestígio e pelo poder efetivamente político, uma vez que as elites dirigentes, ciosas de uma legitimação que a literatura era capaz de conferir, cercavam-se de intelectuais mais influentes do período.

Exemplo disto é a atuação do Barão do Rio Branco como promotor de vários intelectuais (Euclides da Cunha, Aluízio Azevedo, Graça Aranha, Silvio Romero), fazendo indicações políticas de cargos ou apoiando suas pretensões com seu prestígio pessoal.

(...) os autores surgiram como um atavio necessário, na medida em que contribuiriam para consolidar a imagem austera de uma sociedade ilustre e elevada, merecedora da atenção e do crédito europeu incondicional. Imagem que não escapou à visão arguta de Rio Branco... (Sevcenko, 1989, p.94)

Este "mecenato" praticado pelas elites dirigentes do país seria o reflexo do prestígio do homem de letras, conforme nossa herança cultural francesa, influenciando tanto a burguesia nacional como as famílias abastadas da oligarquia, portadoras de um caráter patriarcal e senhorial.

Desta forma fica compreensível a institucionalização de um "mecenato oficial" pelo Barão do Rio Branco e as atitudes de um Freitas Vale. A conseqüência sociológica desta instituição será o caminho 
inexorável para a servidão burocrática dos intelectuais, cada vez mais absorvidos pela legitimação oficial, onde não há espaço para a rebeldia ou para o novo.

A preocupação com a manutenção de seu status de elite intelectual, da qual se esperava a competência para os debates da atualidade, vai acarretar novas transformações e acomodações nas formas de atuação dos intelectuais.

O aproveitamento das contingências do momento era a oportunidade para que a elite intelectual iniciasse a construção de um projeto viável de hegemonia sobre o "pensar a realidade nacional", assumindo uma posição elevada de observador privilegiado e capaz de apontar os rumos para a sociedade, adquirindo definitivamente o caráter missionário da profissão intelectual (Sevcenko, 1989).

\section{Oswald de Andrade, Intelectual entre dois mundos}

A vida literária era então ditada pelo ritmo da capital da república, transformada em pólo de atração de escritores das províncias que desejavam o sucesso e o reconhecimento público; porém, já surgiam novos focos de irradiação cultural nas províncias, principalmente em São Paulo, onde a aglutinação dos jovens da classe dominante se dava a partir da Faculdade de Direito, entendida como preparadora das futuras lideranças políticas e culturais (Adorno, 1990).

É neste contexto que surgem as primeiras revistas e jornais literários, com destaque para a participação de Monteiro Lobato na revista "Arcádia Acadêmica" em 1901 e depois no jornal O Minarete em 1903. Neste último já podemos perceber uma atitude de inquietação frente ao marasmo literário da época e algo que parecia anteceder as "extravagâncias modernistas" (Broca, 1956, p.227).

Em 1911 surge $O$ Pirralho, dirigido por Oswald de Andrade, considerada a revista mais importante do período em São Paulo, pelo seu caráter humorístico e literário que alcançavam aspectos de crítica social e política.

Verdadeira revista de transição, conciliava em suas colunas textos em estilos consagrados pela época com textos que já prenunciavam uma ruptura pela irreverência, como era o caso da participação de Juó Bananére e seu dialeto ítalo-paulista. 
Sintonizado com a vida literária da época, $O$ Pirralho realizou também inquéritos, à moda de João do Rio, sobre o estado das letras na capital da República. Este sincronismo com a realidade presente mais atual é um dos traços que caracterizam desde cedo a atuação do jovem Oswald de Andrade.

O contato de Oswald de Andrade com a vida literária da capital é ainda verificada pela proximidade que mantinha com Amadeu Amaral, cuja eleição para a Academia de Letras foi apoiada por Oswald, que angariou votos junto a seu tio Inglês de Souza, e com outros acadêmicos como Bilac e Humberto de Campos, incluindo também a colaboração destes escritores em artigos d' $O$ Pirralho, como a publicação de uma página em homenagem a Amadeu Amaral, por ocasião de sua morte em 1914 (Broca, 1956, p.367).

O contato entre literatura e política, existente na carreira de Oswald desde 1909, quando era repórter do Diário Popular, mantém-se presente nas páginas d'O Pirralho, que apoiava a campanha civilista de Rui Barbosa, mesmo fazendo restrições ao culto da língua portuguesa, do qual Rui era o expoente.

Foi também na coluna Lanterna Mágica que Oswald pela primeira vez escreveu um artigo, em 1915, em defesa de uma pintura nacional, semeando os primeiros passos do que seria a bandeira das artes plásticas no modernismo e aconselhando os jovens pintores, que traziam na bagagem as novas técnicas da Europa, a:

...se desembaraçarem das recordações de motivos picturais que tiverem (...) e, incorporados ao nosso meio, à nossa vida, tirem dos recursos imensos do país, dos tesouros de cor, de luz, de bastidores que o circundam, a arte nossa que afirme, ao lado do nosso intenso trabalho material de construção de cidades, e desbravamento de terras, uma manifestação superior de nacionalidade. (Andrade, 1992, p.142)

Quem fala aqui é o Oswald cosmopolita, que já havia visitado a Europa em 1912 e que trazia na cabeça as seguintes divagações:

Por que eu gostava mais da Europa do que do Brasil? (...) Era, sem dúvida, a existência livre de artistas, com amores também livres, a boêmia (...) A irregularidade, a contravenção para que eu nascera e para a qual agora escapava... (Andrade, 1976, p.67) 
Registrando a emergência das ambigüidades que com ele conviveriam durante toda a vida, como herdeiro da liberdade boêmia aprendida com Emílio de Menezes e Indalécio Aguiar, combinada com a possibilidade financeira de sua situação social e a inserção em um processo de construção das instituições negadoras daquela mesma liberdade, operando controles sobre a vida intelectual.

Da mesma forma que sua revista, Oswald nos aparece como símbolo vivo do intelectual no limite entre dois "mundos": moldado no convívio dos primeiros boêmios da linhagem de Emílio de Menezes e depois freqüentando a chamada "boêmia dourada" dos salões, nos quais teve a iniciação garantida pela condição de membro da elite dominante, e tendo como companheiros de convívio os expoentes da Academia de Letras no Rio (Bilac, Olegário Mariano, Amadeu Amaral, etc.).

Porém, ao mesmo tempo, não se deixa imobilizar pela facilidade de adaptação e conformismo dos padrões estabelecidos e, com pouco mais de 20 anos, já cultiva as atitudes de busca permanente pelo novo, que o acompanharão por toda a vida.

É assim que, entre 1917 e 1918, aluga e mantém uma garçonnière à Rua Libero Badaró, onde estreita relações com outros nomes da intelectualidade paulista, na ânsia de agitar a vida cultural da cidade e de fazer melhor compreender as novas tendências estéticas que conhecera na Europa.

Freqüentam a garçonnière Menotti del Pichia, Monteiro Lobato, Léo Vaz, Guilherme de Almeida, Ignácio Ferreira (o caricaturista Ferrignac), Pedro Rodrigues de Almeida, Sarti Prado e a musa animadora de todos, Dayse, a "miss Ciclone". Os encontros são registrados em um diário coletivo chamado "O Perfeito Cozinheiro das Almas deste Mundo", onde pode ser encontrada toda a riqueza das discussões e do panorama intelectual em que viviam aqueles jovens, suas preocupações com os rumos da guerra, os acontecimentos literários e, também, o desenrolar do agitado romance entre Oswald e Dayse.

O espírito inquieto de Oswald de Andrade logo faria com que organizasse uma nova garçonnière, agora na Praça da República, e que também, em 1920, editasse a revista Papel e Tinta, com a colaboração de Mário de Andrade, Guilherme de Almeida, Léo Vaz e Monteiro Lobato, reforçando a determinação de arejar o ambiente literário e cultural dominado então pelo oficialismo das produções de 
Olavo Bilac e Coelho Neto, que limitavam, assim, o espaço para as novas tendências estéticas e os novos escritores.

Na esteira da efervescência intelectual, também em São Paulo, em 1916, surgia a Revista do Brasil, fundada por Júlio de Mesquita, Plínio Barreto e Alfredo Pujol, que, com espírito bastante diverso d'O Pirralho, rejeita qualquer mundanismo e propõe-se a ser um pólo centralizador das discussões sobre a dimensão cultural do país, incluindo as questões do nacionalismo e da formação de uma consciência brasileira.

A mesma revista vai reaparecer na década de 20 sob direção de Paulo Prado e Monteiro Lobato, mantendo-se fiel ao seu caráter de discussões sérias e de qualidade, sem porém deixar de abrir espaços a alguns jovens modernistas como Mário de Andrade e Sérgio Milliet.

Segundo Brito Broca, a Revista do Brasil seria o contraponto da demolição prenunciada por $O$ Pirralho, servindo de preparação do terreno para a "fase construtiva que havia de seguir-se à demolição".

Neste sentido já é possível perceber uma primeira pista daquele processo valorativo que viria a marcar definitivamente os rumos da vida intelectual do país após a eclosão - e a rotinização - do movimento modernista de 1922.

A postura de Oswald de Andrade contrapunha-se à idéia tradicional, existente em todos os embates da história da literatura, onde um momento inicial de "terror" e destruição deveria servir apenas como demarcação das diferenças, devendo ser seguido por um movimento de construção.

Ocorre, porém, que neste caso, esta "construção" seria sinônimo de uma nova cristalização, que explicita a profunda incompreensão daquela dimensão defendida, principalmente por Oswald de Andrade, de entender o movimento modernista como portador da possibilidade de um processo contínuo de demolição e construção, superando assim aquela lógica tradicional de "escolas" que se sucedem.

O aparecimento destas publicações em São Paulo representou uma equalização da efervescência da vida intelectual da província com aquela da capital da república, explicitando também um contraste latente entre as rápidas mudanças por que passava a cidade de São Paulo e a imobilidade dos padrões e comportamentos estabilizados pela vida literária oficializada no Rio de Janeiro. 
A iminência de uma ruptura necessária já existia na consciência de Oswald, que relembra o limite que existia para quem desejasse atuar na vida literária do Rio de Janeiro:

Quando pensei em fazer literatura, precisei aproximar-me dos donos do jornalismo, do reclame, da Academia. Mas não consegui afinar com aquela gente, apesar de freqüentá-la e de ter encontrado, em São Paulo, um espírito simples e amável, que foi Amadeu Amaral. (Andrade, 1990, p.162)

Embora a capital fosse caracterizada pelo caráter cosmopolita de sua vida intelectual, intimamente relacionada a um estilo de vida importado de Paris, visível nas posturas pessoais e também na paisagem "civilizada" que a virada do século imprime na cidade, a existência de um ritmo já institucionalizado pesou como obstáculo às atitudes de mudança nesta situação.

Já em São Paulo, embora a mentalidade provinciana predominasse, o ritmo da vida agitava-se no compasso das novas influências estrangeiras na política, no trabalho, nos esportes e no cinema - que modificou tanto as formas de percepção da realidade, exemplificadas nas crônicas fragmentárias e despreocupadas de João do Rio, como a moralidade da cidade, criando antagonismos com as antigas proibições e interditos da moral provinciana.

Estas diferenças na apreensão dos ritmos de vida entre o Rio e São Paulo foram percebidas pelos modernistas, que as aproveitaram em favor de seu movimento de ruptura, pois o provincianismo paulista era o fator imprescindível que possibilitava uma atitude de "espanto" que pudesse se transformar efetivamente em disputa concreta.

Mário de Andrade, em sua conferência de 1942, intitulada "O Movimento Modernista", percebe claramente as conseqüências destas particularidades ao comentar a repercussão da exposição de Anita Malfatti em 1917:

Ora, no Rio, malicioso, uma exposição como a de Anita Malfatti podia dar reações publicitárias, mas ninguém se deixava levar. $\mathrm{Na}$ São Paulo sem malícia, criou uma religião. (Andrade, 1974, p.236)

Assim, era inevitável que novas instituições e novos hábitos começassem a surgir, para fornecer uma possibilidade de resposta aos novos 
tempos. No contexto desta transformação dos ritmos da cidade - de uma vila provinciana para uma cidade industrial - a própria paisagem humana torna-se estranha para o paulistano, ainda não acostumado com o surgimento da multidão como elemento de seu dia-a-dia, surpreendido também pelas primeiras greves operárias em 1917 e manifestações anarquistas influenciadas pela maciça presença do imigrante italiano.

No bojo destas transformações, a idéia de modernidade começava a adquirir notoriedade e a tornar-se corriqueira no cotidiano da cidade, como sinônimo de novidade, exotismo ou revolução (Sevcenko, 1992, p.227), impregnando tudo a que se referia com uma aura de autonomia frente à tradição.

A força do "moderno" colocava São Paulo na mesma esteira de progresso das metrópoles européias, potencializando as expectativas para um futuro otimista, capaz de estimular o rompimento com aqueles laços antigos que regiam a vida dos indivíduos (Sevcenko, 1992).

No registro da política, a modernidade também contrapunha os novos métodos de racionalidade administrativa aos dispositivos arcaicos dos grupos que exerciam o poder, transformando-se numa arma de oposição que levou aqueles grupos hegemônicos a se preocuparem em também inserir-se nesta modernidade.

Desta forma é que se compreende o duplo sentido da "feição aristocrática" que definiu o movimento modernista em São Paulo, pois, se por um lado a elite dirigente "esclarecida" tem a necessidade de aderir à modernidade, por outro lado,

só um grupo cuja curiosidade intelectual pudesse gozar de condições especiais como viagens à Europa, leitura dos derniers cris, concertos e exposições de arte, poderia renovar efetivamente o quadro literário do país. (Bosi, 1982, p.377)

Daí o envolvimento no processo de legitimação e de organização dos eventos culturais, desde a Exposição de Pinturas Francesas no Municipal em 1916 - feita por Paulo Prado e pelo senador Freitas Valle - até a campanha de propaganda dos artistas da Semana de 22, mesclando uma preocupação em definir as raízes de uma cultura popular nacional, com marcas profundas no regionalismo paulista ${ }^{1}$. 
Assim, encontramos em São Paulo tanto os elementos que marcavam a entrada do país na modernidade como o conflito entre as elites tradicionais - os fazendeiros de café - e as novas forças emergentes da indústria, ambas percebendo a necessidade de reconstruir suas posições de poder a partir da busca de um projeto de cultura nacional capaz de lhes conferir a legitimidade necessária para a substituição daqueles nexos sociais e políticos que haviam sido destruídos pela emergência do tempo moderno.

Era inevitável que tais transformações exigissem novas formas de enfrentamento e de posicionamento na realidade cultural e política na sociedade. A situação de marasmo da capital federal contrastava com a multiplicidade de idéias novas surgidas em São Paulo, definindo uma situação onde, nas palavras de Morse,

Somente uma geração nascida depois de 1890 - e que desde a infância tivesse tomado contato direto com a nova ordem sem a censura dos símbolos interferentes da velha ordem - poderia, ao chegar à maturidade, dar articulação à idade moderna. (Morse, 1954,p.271)

Compreendemos então a existência de um processo que torna a participação na vida intelectual viável somente a partir do enquadramento nas instituições culturais herdadas do começo do século, seja pelo reconhecimento da Academia Brasileira de Letras, pela constância dos artigos em jornais ou pela dependência do "mecenato oficial" patrocinado pela burocracia estatal, definindo-se assim os critérios de inserção ou exclusão, limitando a possibilidade de uma autonomia intelectual.

A partir da emergência de uma consciência intelectual que superasse o mundanismo esteticista e convocasse os escritores a participar das questões culturais nacionais em escala mais ampla, e também a partir da "novidade" modernista, será possível vislumbrar outras possibilidades de atuação na vida cultural, determinada principalmente pelo engajamento político nos anos 30 que vai incorporar novas formas de intervenção legítima para esta atuação.

Ocorre, porém, que ao intelectual estas possibilidades de atuação vão continuar representando, no fundo, uma falsa escolha, uma vez que as opções colocadas serão a de integrar-se aos novos padrões ou manter-se no segundo plano da vida cultural, pois a definição do 
reconhecimento destes intelectuais vai estar cada vez mais centrada nas instâncias inerentes à construção institucional da nova ordem política que dirigirá o país. ${ }^{2}$

Estes novos embates ideológicos vão agitar o cenário cultural do país e transferir o foco de importância cultural do Rio de Janeiro para São Paulo, sem realizar, contudo, nenhuma ruptura absoluta, uma vez que a Academia de Letras vai continuar sendo, mesmo nos momentos de clímax do movimento modernista, uma instituição que, se por um lado é alvo constante de críticas, por outro lado consegue manter-se pelo menos indiferente àquela "revolução", permanecendo como representante oficial das iniciativas literárias legitimadas, inclusive conseguindo manter sua "irresistível" força de atração que acabará por inserir em suas fileiras muitos dos modernistas de primeira hora.

De qualquer maneira, a trajetória possível para o intelectual já estará neste momento inserida em uma lógica que vai exigir o delineamento de estratégias cada vez mais sistemáticas de legitimação de suas vertentes, num movimento que, se por um lado rompeu com a tradição acadêmica e seu privilégio de reconhecimento, por outro lado vai encontrar-se prisioneiro das mesmas necessidades que levarão à uma institucionalização de sua possível revolução.

Assim, se nos detivemos nas considerações sobre uma certa "herança boêmia", como constatação de que o jovem Oswald de Andrade não estava infenso ao modo de vida daqueles que desejavam iniciar-se na vida intelectual (definida pela literatura e pelo jornalismo), foi para termos nosso horizonte ampliado através da análise da forma singular como se deu aquela conjunção ímpar entre a personalidade de Oswald de Andrade e os espaços existentes no sistema cultural.

Daí, seria através do desafio da compreensão da situação "marginal" em que se encontrava Oswald de Andrade em relação àquele establishment cultural, ele mesmo a força avassaladora que lhe permitia realizar a permanente negação dos consensos absolutos ${ }^{3}$, que poderíamos tentar compreender melhor as permanências daquele mundo e seu modelo nas estruturas de nossa atualidade.

Finalmente, a possibilidade de uma atuação nos moldes daquela liberdade experimentada por Oswald de Andrade nos momentos anteriores à ruptura modernista e mantida em sua "fase heróica" vai deparar-se com as questões colocadas acima, e sua conciliação se mostrará complexa no novo cenário que começava a surgir. 


\section{Notas}

1 Uma análise da atuação de Paulo Prado, entendida no âmbito da tradição política de sua família e a sua preocupação com a "redescoberta" do Brasil pode ser aprofundada no livro de Darrel Levi, A Família Prado.

2 A análise feita por Sérgio Miceli sobre as relações entre intelectuais e Estado, cujo clímax se deu no governo Vargas, vai ilustrar como o Estado passa por um movimento que o transforma em legitimador das competências ligadas ao trabalho intelectual. Daí sua afirmação de que "os parâmetros que passaram a nortear o trabalho intelectual parecem indissociáveis do projeto de hegemonia política então formulado pelos grupos dirigentes locais" (Miceli, 1979, p.189).

3 Para Turner, é exatamente a condição marginal que pode proporcionar um locus privilegiado para a criatividade humana: "A liminaridade, a marginalidade e a inferioridade estrutural são condições em que freqüentemente se geram os mitos, símbolos rituais, sistemas filosóficos e obras de arte. Estas formas culturais proporcionam aos homens um conjunto de padrões ou de modelos que constituem, em determinado nível, reclassificações periódicas da realidade(...) Todavia são mais que classificações, visto incitarem os homens à ação tanto quanto ao pensamento" (Turner, 1974, p.156).

Abstract. This article is a essay to understand the limits of the autonomy of intellectual life in São Paulo, in the early years of the 20th century. Following the track from the modernist writer Oswald de Andrade, his participation in the bohemian groups from Rio de Janeiro and in the modernist group from São Paulo in 1922, we will analyze how works the process of institutionalization of culture in terms of building a new pattern to permit recognition and legitimization for intellectual life.

Resumé. Cet article s'agit d’un travail sur les limites de la autonomie de la vie intellectuelle a São Paulo dans les premières annés du XXéme siècle. Nous irons acompagner les chemins du Oswald de Andrade depuis son participation aux groupes de la boemie au Rio de Janeiro jusqu'á son participation célebre dans le Mouviment Moderniste à São Paulo en 1922, pour 
découvrir comment s'a dévellopé le processus d'institucionalisation de le domaine de la culture et comment fut defini un nouveau standard pour la reconaissance et pour la legitimation de la vie intellectuelle.

\section{Referências Bibliográficas}

Adorno, Sérgio (1990). Os aprendizes do poder, São Paulo: Brasiliense.

AndRade, Mário de (1974). Aspectos da literatura brasileira. São Paulo: Martins.

Andrade, Oswald de (1976). Um homem sem profissão. Rio de Janeiro: Civilização Brasileira.

(1990). Os dentes do dragão. São Paulo: Globo. (1992). Estética e política. São Paulo: Globo.

BosI, Alfredo (1982). História concisa da literatura brasileira. São Paulo: Cultrix.

Broca, Brito (1956). A vida literária no Brasil - 1900. Rio de Janeiro: Ministério da Educação e Cultura - Serviço de Documentação.

Campos, Humberto de (1954). Diário secreto. Rio de Janeiro: Edições O Cruzeiro.

CÂNDIDO, Antônio (1985). Literatura e sociedade. São Paulo: Cia. Editora Nacional.

Levi, Darrel E. (1977). A Família Prado. São Paulo: Cultura 70.

Martins, Wilson (1977). O Modernismo. São Paulo: Cultrix.

Miceli, Sérgio (1977). Poder, sexo e letras na República Velha. São Paulo: Perspectiva.

(1979). Intelectuais e classe dirigente no Brasil. Rio de Janeiro: Difel.

Morse, Richard M. (1954). Da comunidade à metrópole biografia de São Paulo. São Paulo: Comissão do IV Centenário de São Paulo. 
Neto, A.L. Machado (1973). Estrutura social da república das letras: Sociologia da vida intelectual brasileira (1870 1930). São Paulo: Grijalbo.

Rio, João do (1994). O momento literário. Rio de Janeiro: Fundação Biblioteca Nacional/ Dept. ${ }^{\circ}$ Nacional do Livro.

Sevcenko, Nicolau (1989). A literatura como missão. São Paulo: Brasiliense.

(1992). Orfeu extático na cidade. São Paulo:

Cia. das Letras.

Sussekind, Flora (1987). Cinematógrafo das letras. São Paulo: Cia. das Letras.

Turner, Victor (1974). "Liminaridade e comunitas". In: O Processo Ritual. Rio de Janeiro: Vozes. 